\section{Géneros}

Multidisciplinary Journal of Gender: Studies

\section{Hipatia Press \\ www.hipatiapress.com}

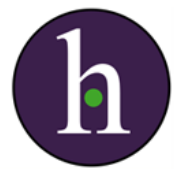

Instructions for authors, subscriptions and further details:

http://generos.hipatiapress.com

\title{
Employment, Motherhood and Wellbeing: A Discourse on the Trio within Public Organisations in Southwest Nigeria
}

Babatunde Joshua Omotosho ${ }^{1}$

1) Federal University Oye-Ekiti. Nigeria

Date of publication: February $25^{\text {th }}, 2017$

Edition period: February - June 2017

To cite this article: Omotosho, B.J. (2017). Employment, Motherhood and Wellbeing: A Discourse on the Trio within Public Organisations in Southwest Nigeria. Multidisciplinary Journal of Gender Studies, 6(1), 1263-1287. doi: 10.4471/generos.2017.2223

To link this article: http://dx.doi.org/10.4471/generos.2017.2223

\section{PLEASE SCROLL DOWN FOR ARTICLE}

The terms and conditions of use are related to the Open Journal System and to Creative Commons Attribution License (CC-BY). 


\section{Employment, Motherhood and Wellbeing: A Discourse on the Trio within Public Organisations in Southwest Nigeria}

Babatunde Omotosho

Federal University Oye-Ekiti

\section{Abstract}

African women in public service experience some issues in their bid to juggle between their jobs and parenting; however, not much is available within the literature to explain these dynamics. This study seeks to document this by understand their experiences, the coping strategies adopted and the implications on the respondents' wellbeing and that of their children. For quantitative data, a total number of one hundred and sixty questionnaires were purposively administered to mothers with infants working within the selected organizations and complemented with twenty in-depth interview schedules. Findings: a majority ( 40.0 percent) of the respondents were aged 31-40 years. About 73.0 percent claimed their challenges include how to combine paid employment with motherhood while 26.9 percent attributed it to finance. Respondents mentioned that their children experience diarrhoea and malaria (22.2 percent), loss of appetite and weakness (23.1 percent) while they are away to work. On the part of the mothers, 62.3 percent claimed that their major challenges are stress and in ability to focus on their work. Respondents further argued that child spacing (7.5 percent) and support from husband (17.5 percent) are part of their coping mechanisms. Working mothers need a more conducive atmosphere for career development and parenting.

Keywords: woman, motherhood, child, Nigeria, employment 


\section{Empleo, maternidad y bienestar: un discurso sobre el trío dentro de las organizaciones públicas en el suroeste de Nigeria}

Babatunde Omotosho

Federal University Oye-Ekiti

\section{Resumen}

Las mujeres africanas en el servicio público experimentan problemas en su intento de combinar sus trabajos con la crianza de los hijos; Sin embargo, no hay mucha literatura disponible para explicar esta dinámica. Este estudio pretende documentarlo mediante la comprensión de sus experiencias, las estrategias adoptadas y sus implicaciones en el bienestar de las encuestadas y en el de sus hijos. Para los datos cuantitativos, un total de ciento sesenta cuestionarios fueron intencionalmente administrados a madres con niños, que trabajan dentro de las organizaciones seleccionadas, y complementadas con veinte entrevistas en profundidad. Conclusiones: la mayoría (40\%) de las encuestadas tenían entre 31 y 40 años. Cerca de $73 \%$ afirmó que sus desafíos incluyen cómo combinar el empleo remunerado con la maternidad, mientras que $26.9 \%$ los atribuyó a la financiación. Las entrevistadas mencionaron que sus hijos experimentan diarrea y malaria (22.2\%), pérdida de apetito y debilidad (23.1\%) mientras ellas están ausentes para trabajar. Por parte de las madres, el 62,3\% afirmó que sus principales desafíos son el estrés y la capacidad de centrarse en su trabajo. Las encuestadas argumentaron además que el distanciamiento de los hijos (7,5\%) y el apoyo del marido (17,5\%) son parte de sus estrategias. Las madres trabajadoras necesitan un ambiente más propicio para el desarrollo profesional y la crianza de los hijos.

Palabras clave: mujeres, maternidad, hijo, Nigeria, empleo 



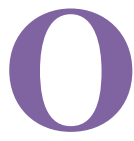

ne of the variants of modernisation includes the involvement of women in paid employment. This development implies that women who over time were full housewives and mothers had to divide their time between paid employment and family care. This has implications on the family structure, child health and development (Basu, 1992). In the last 40 years, women involvement in labour force has increased dramatically across the globe (Hielman and Okimoto, 2008). Notwithstanding and comparatively, mothers face stiffer challenges than women that are yet to give birth (Hielman and Okimoto, 2008). The impact of this situation on the social, psychological and physiological conditions of these mothers cannot be overemphasized. Correll, Bernard and Park, (2007); Gungor and Biernat, (2009) while investigating the dynamics of employment on mothers emphasized that the rigors surrounding work often undermine the competence of mothers in their chosen fields. Aside these, the economic impact on the mothers have been found to be enormous. Budig and England (2001) for instance in their study found out that employed mothers in the United States on average experience a five percent wage penalty per child after controlling other factors that affect earnings. Ridgeway and Correll (2004) also looked at the social label placed on women as being unable to do the expected job based on the assumption that she is a nursing mother, the belief is that a mother is unable to do the normal working hours due to her status as a mother even in situations where the employed mother is discharging her duty effectively. Aside the above, the issue of glass ceiling is also a strong factor affecting these mothers, a situation whereby women based on social factors are not allowed to rise to their desired status. Some of the reasons often associated with this include the perception that they are too feminine and as a result of that they are often perceived as not qualified and competent enough because they are nursing women and if they choose not to be feminine, they regard them as lacking social skills expected of a woman (William, 1992).

This situation is same in Africa and Nigeria is not left out. While studies on the conditions of mothers within work place are scanty, available ones suggest that juggling between work and child care is a challenge to them. Evidence available regarding the plight of women within the workplace still suggests marginalization, unpleasant polices against women and the rest. 
Women constitute 45 percent of the estimated 150 million populations in Nigeria, yet their involvement in leadership positions is not proportionate to their population. Mothers in private organizations do not enjoy the compulsory 3 months' maternity leave especially in private organizations; those working in cities struggle with the demands of urban centres and quite a number of them suffer cultural injustices in within the work environments (Sun news, 2013). Beyond that, the cultural limitations placed on women due to patriarchy also constitute a challenge for working mothers; quite a majority of them have to combine domestic chores with office work and child care. Evidence further suggests that the current situation may worsen (Hein and Cassirer, 2010; Leslie, 1989). The impact of this marginalization on the children cannot be ignored as well. Studies have revealed that the kind of provision for child care in developing countries has failed to meet the present needs of mothers and children (Hein and Cassirer, 2010; Leslie, 1989; Joekes, 1989). The long and short run implication of inadequate child care is high; failure to pay adequate attention to child care from the beginning may expose these children to a number of challenges ranging from malnutrition stress unemployment, increased poverty and among others. Going by these developments, investigating the dynamics of motherhood workplace vis-à-vis mothers and child wellbeing thus becomes critical.

Studies have showed that women form almost half of the total workforce and the figure is expected to rise sharply at the first half of the 21st century (Falzon, 2007; Orr, 1997). Further, it is an established fact that women workers are an essential part of the work system and cannot be dispensed with in any way (Barnett, Marshall \& Sayer, 1992). However, in spite of their uniqueness and qualities, women still suffer challenges due to a combination of work and child care. For instance, Hoffman (1963) observed in his study that work stress has an influence on the quality of the parent-child interaction. Falzon (2007) equally submitted that 78.0 percent of working women still come back home to look after their children when they close from work. The implication of this is that mothers combine two jobs at the same time- a paid employee and a nursing mother. The children are not left out of this encounter; studies reveal that lack of contact between children and parents was directly responsible for the rising levels of mental health problems, sleep disorders and other socio-psychological issues others 
(Falzon, 2007). Ammaniti, et al (2004) also saw that separating children from their parents store up behavioural difficulties for them. These myriads of events within these spaces suggest an investigation of the methods and strategies adopted by mothers to meet the demands of workplace and child care. Further, an assessment of these strategies in relation to the health and welbeing of the child also becomes necessary in this study.

Within the literature, combining the roles of motherhood and work has been regarded as a combination of multiple roles and it has not attracted the required attention. Mothers working outside the home often find it challenging to combine health responsibilities and employment demands, more especially among low income women (Kaiser Family Foundation, 2003). Examining dynamics of motherhood, workplace and child care thus becomes important as one of the means to further throw light to these issues and with the aim of finding lasting solution to some of the challenges women face as mothers within the work places.

The following are the research questions formulated for the study:

\section{Research Questions}

a) What are the socio-economic and demographic characteristics of the respondents?

b) What are the coping strategies adopted in combining motherhood and employment?

c) What are the challenges they face in combining motherhood and employment?

d) What are its implication on their health and that of their child?

The following are the objectives of the study:

\section{Objectives of the Study}

The general objective of the study was to examine the experiences of working mothers to work, motherhood and wellbeing in public organisations in Southwest Nigeria. 
The specific objectives were to:
a) Examine the socio-economic and demographic characteristics of the respondents
b) Understand the challenges respondents face in combining motherhood and employment.
c) Assess its implication on the mother and child's health and wellbeing
d) Assess the coping strategies of the respondent in combining motherhood and employment

\section{Brief Literature review}

\section{Women, work and child care: a brief discourse}

The dynamics of motherhood and work may not be strange in Africa and Nigeria in specific. From pre-colonial through colonial era, women have engaged in different forms of work as a means of survival and as part of their contributions to the maintenance of the family. Women were farmers, traders and some have in the process extended their trade beyond their localities (Omoruyi, 1994).

In some cultures, in Nigeria for instance, some women were found to have excelled in their chosen careers more than their male counterparts. They were able to successfully combine their jobs with child care based on the flexibilities of their jobs. As a matter of fact, in traditional African settings, caring for the children was never a challenge to working mothers basically because the nature of their jobs permitted that. Aside this, the communal lifestyle as reflected in social and housing structure in traditional African societies permitted working mothers to leave their children with the older children if available, or elderly women within the homestead who could no longer do strenuous activities. Thus, children within a particular homestead belonged to all members of that homestead and would be cared for by all. However, with the emergence of paid employment and industrialization in Nigeria, there was a breakdown of this lifestyle such that nuclear families became separated from the extended families. However, the patterns of work changed drastically about fifty years back due to industrialization such that work became more formalized (ILO, 
2010; Chete, Adeoti, Adeyinka and Ogundele, 2014). This development in the country no doubt is an extension of what obtained in developed countries. The developing countries are gradually modelling its work and family patterns after the west yet, the structures needed to make this work has not been successfully put in place. ILO (2010), while explaining the differences at the regional and sub regional levels among developing countries argues that between 1950 and 1985, the proportion of women aged 15 or older in the paid labor force rose from 37 to 42 percent. This of course represents a fraction of women in labor participation as larger percentage of women in Sub Saharan Africa is engaged in informal employments. Notwithstanding, the percentage of economically active women is high, but it appears to have actually declined from slightly above to slightly below 50 percent in the period since 1970 (ILO, 2010).

Joekes (1989) categorized the sources of non-maternal child care into four areas; the first she referred to as 'non-existent' child care which to her is the most frequent child care practice adopted globally. This arrangement is such that children are left unattended to when mothers are busy. The second type has to do with the child care being provided for by members of the household, especially by older siblings. The third type of child care plan relates to exchange of child care among family members and neighbors usually without any financial obligation attached to such exchange of services. The fourth which is the last relates to child care being handled by professionals whether at the formal or informal level for a fee. Joekes (1989) typology provides a description of child care across the globe and as a matter of fact almost all of them are practiced in this part of the globe. The second and the fourth child care plans are however very common among nursing mothers in Nigeria. The reason is simple, they are most times far from their extended families and they need to be close to their children and the demands of modernization are also very important.

\section{Methods}

A total of one hundred and sixty female working mothers were selected from government establishment in Ado Ekiti, the state capital of Ekiti state through a purposive sampling technique over nine major ministries across the government secretariat. By working mothers, we refer to mothers having children between ages 3 months and 2 years. The reason for this 
sampling procedure was because of the nature of the research, which had to look for working mothers within the work setting. In eliciting data from the respondent, the study employed both quantitative and qualitative methods. Questionnaires containing open ended and closed-ended questions were used. Qualitative data involved the use of in-depth interview to capture deeper meanings and insights into the research. A total number of twenty respondents were selected for the in-depth interview. Both quantitative and qualitative data were analyzed accordingly. The questionnaires were analyzed through Statistical Package for Social Science (SPSS) software while the in-depth interview was analyzed and quoted where necessary to support the data from questionnaire. Three hypotheses were tested for this study. They are listed below in alternate forms; chi-square statistical technique was used to identify the direction of the relationship:

1. There is a significant relationship between age and finding parenting and employment easy.

2. There is a significant relationship between marital status and finding parenting and employment easy.

3. Respondents who give in their best to work often find motherhood and employment an easy task

\section{Result Findings}

This section (see Table 1) explains the percentage distribution of respondents' age, education, marital status and professional qualification. Findings on age revealed that respondents between age 31 and 40 dominated the study constituting 40.0 percent. The least were respondents aged 20 and below (10.0 percent). This may not be strange considering the requirements as regards entry into labour force. This is further reflected on the respondents' educational qualification as respondents with tertiary education and professional qualification formed the majority with 32.5 percent and 42.5 respectively. Findings on the marital status also revealed that a majority of the respondents were married. 
1271 Omotosho - Employment, Motherhood and Wellbeing

Table 1

Percentage Distribution of Respondents Based on Selected Socio-Economic Variables

\begin{tabular}{|l|l|l|}
\hline Age & Frequency & Percentage \\
\hline Below 20 years & 16 & 10.0 \\
\hline $21-30$ years & 28 & 17.5 \\
\hline $31-40$ years & 64 & 40.0 \\
\hline 41 and above & 52 & 32.5 \\
\hline Total & 160 & 100.0 \\
\hline Education & Frequency & Percentage \\
\hline Primary & 8 & 5.0 \\
\hline Secondary & 32 & 20.0 \\
\hline Tertiary & 52 & 32.5 \\
\hline Professional qualification & 68 & 42.5 \\
\hline Total & 160 & 100.0 \\
\hline Marital status & Frequency & Percentage \\
\hline Married & 136 & 85.0 \\
\hline Separated/divorced & 24 & 15.0 \\
\hline Total & 160 & 100.0 \\
\hline & & \\
\hline
\end{tabular}

From the table (see Table 2), majority of the respondents earn between 20000 and 40000 in a month; this of course may be a reflection of the salary structure in the country. Aside that, quite a number of them from indepth and questionnaire have spent between 1 and 5 years in the organization. Equally, a total of 9 departments (ministries) were involved in the study with Women Affairs constituting 17.5 percent.

Table 2:

Percentage Distribution of Respondents Based Income and Departments

\begin{tabular}{|l|l|l|}
\hline Income & Frequency & Percentage \\
\hline$*{ }^{1}$ Below 20,000 & 12 & 7.5 \\
\hline $20,001-30000$ & 60 & 37.5 \\
\hline $30001-40000$ & 56 & 35 \\
\hline 40,001 and above & 32 & 20 \\
\hline Total & 160 & 100.0 \\
\hline
\end{tabular}

${ }^{1}$ As at the time of the research, 1 US dollar was equivalent to 160 Nigeria Naira 


\begin{tabular}{|l|l|l|}
\hline Department & Frequency & Percentage \\
\hline Health & 12 & 7.5 \\
\hline Justice & 8 & 5 \\
\hline Lands and Environment & 28 & 17.5 \\
\hline Women Affairs & 28 & 17.5 \\
\hline $\begin{array}{l}\text { Commerce Industry and } \\
\text { Cooperative }\end{array}$ & 16 & 10.0 \\
\hline $\begin{array}{l}\text { Information and Civic } \\
\text { Orientation }\end{array}$ & 20 & 12.5 \\
\hline $\begin{array}{l}\text { Agriculture and Natural } \\
\text { Resources }\end{array}$ & 16 & 10.0 \\
\hline Education and Technology & 16 & 10.0 \\
\hline Establishment and Training & 16 & 10.0 \\
\hline Total & 160 & 100.0 \\
\hline
\end{tabular}

The respondents (see Table 3) were asked to assess whether they are able to give in their best to their work place as mothers, and a majority of the respondents submitted in the affirmative. A number of reasons were given by the respondents as responsible for their responses. They submitted that they come to work as at when due (45.9 percent) and do all tasks assigned to them (54.1 percent). Only 8.8 percent of the respondents felt they were not doing enough for working moms. The major reasons given attributed to this included inability to attend trainings and seminars that can further equip them (42.9 percent) and the opinion that they could perform better than they are doing at the moment (57.1 percent). Hakim (1997) argues one of the determinants for how much to work is often based on sex role attitudes; other studies have also added intentions as key determinants of how much an individual will put into his or her work (Kan 2007; Blozendahl and Myers, 2004). Charles and Harris (2007) summed up the whole argument by emphasizing on the tradition of wanting to do what is right as a strong determinant of putting in the best to work. This tradition of course may propel young mothers to wanting to excel in both work and parenting. 
1273 Omotosho - Employment, Motherhood and Wellbeing

Table 3

Percentage Distribution on Respondent Satisfaction with their Work Performance

\begin{tabular}{|l|l|l|}
\hline $\begin{array}{l}\text { Do you think you are } \\
\text { giving your best to work } \\
\text { as mother? }\end{array}$ & Frequency & Percentage \\
\hline Yes & 146 & 91.2 \\
\hline No & 14 & 8.8 \\
\hline Total & 160 & 100.0 \\
\hline $\begin{array}{l}\text { If yes, why do you think } \\
\text { so }\end{array}$ & Frequency & Percentage \\
\hline $\begin{array}{l}\text { I am always available at } \\
\text { work }\end{array}$ & 67 & 45.9 \\
\hline $\begin{array}{l}\text { I do all that is assigned to } \\
\text { me }\end{array}$ & 79 & 54.1 \\
\hline Total & 146 & 100.0 \\
\hline If no, why not? & Frequency & Percentage \\
\hline $\begin{array}{l}\text { I believe I can do better } \\
\text { than my present } \\
\text { performance }\end{array}$ & 8 & 57.1 \\
\hline $\begin{array}{l}\text { I can't go for training and } \\
\text { seminars }\end{array}$ & 6 & 42.9 \\
\hline Total & 14 & 100.0 \\
\hline
\end{tabular}

This section (see Table 4) examines how the respondents are able to combine motherhood with their jobs.

Table 4

Percentage Distribution on combining motherhood with employment

\begin{tabular}{|l|l|l|}
\hline $\begin{array}{l}\text { How would you assess } \\
\text { combining motherhood } \\
\text { with employment }\end{array}$ & Frequency & Percentage \\
\hline Challenging & 104 & 65.0 \\
\hline Very interesting & 56 & 35.0 \\
\hline Total & 160 & 100.0 \\
\hline Why is it interesting? & Frequency & Percentage \\
\hline $\begin{array}{l}\text { Children are God's } \\
\text { blessing }\end{array}$ & 65 & 62.5 \\
\hline I have assistants & 39 & 37.5 \\
\hline Total & 104 & 100.0 \\
\hline
\end{tabular}




\begin{tabular}{|c|c|c|}
\hline $\begin{array}{l}\text { Why do you find it } \\
\text { challenging? }\end{array}$ & Frequency & Percentage \\
\hline $\begin{array}{l}\text { The nature of my work is } \\
\text { tasking }\end{array}$ & 26 & 46.4 \\
\hline Lack of assistants & 14 & 25.0 \\
\hline I have a large family & 12 & 21.4 \\
\hline I cannot explain & 04 & 7.2 \\
\hline Total & 56 & 100.0 \\
\hline $\begin{array}{l}\text { What would you say is } \\
\text { the major challenge in } \\
\text { combining work and } \\
\text { motherhood? }\end{array}$ & Frequency & Percentage \\
\hline Closing hour & 55 & 34.3 \\
\hline Office demand & 30 & 18.8 \\
\hline Traffic stress after work & 42 & 26.3 \\
\hline $\begin{array}{l}\text { Domestic duties after } \\
\text { work }\end{array}$ & 33 & 20.6 \\
\hline Total & 160 & 100.0 \\
\hline $\begin{array}{l}\text { Do you have crèche close } \\
\text { to your work place? }\end{array}$ & Frequency & Percentage \\
\hline Yes & 140 & 87.5 \\
\hline No & 20 & 12.5 \\
\hline Total & 160 & 100.0 \\
\hline Do you patronize it? & Frequency & Percentage \\
\hline Yes & 116 & 72.5 \\
\hline No & 44 & 27.5 \\
\hline Total & 160 & 100.0 \\
\hline $\begin{array}{l}\text { Have the facilities being } \\
\text { of help? }\end{array}$ & Frequency & Percentage \\
\hline Yes & 108 & 67.5 \\
\hline No & 52 & 32.5 \\
\hline Total & 160 & 100.0 \\
\hline If yes why? & Frequency & Percentage \\
\hline Proximity & 48 & 44.4 \\
\hline My baby likes it & 37 & 34.3 \\
\hline Good facilities & 23 & 21.3 \\
\hline Total & 108 & 100.0 \\
\hline
\end{tabular}




\begin{tabular}{|l|l|l|}
\hline If no why not? & Frequency & Percentage \\
\hline I don't like the place & 26 & 50.0 \\
\hline It is expensive & 15 & 28.8 \\
\hline My child goes to school & 11 & 21.2 \\
\hline Total & 52 & 100.0 \\
\hline
\end{tabular}

From the table, 65.0 percent felt the task was challenging while the rest of the respondents (35.0 percent) claimed they found it very interesting. Buttressing on why they found it challenging, 46.4 percent of the respondents attributed it to the nature of their jobs; while 25.0 percent felt it was challenging because of lack of individuals to assist them. During the IDI sessions, some of the respondents had this to say regarding why they found motherhood and employment challenging:

I am the confidential secretary to my boss, he wants me to be around all the time, sometimes to go and pick up my kids after closing hour is difficult; I have to come to work very early and I may not leave until my boss is done for the day. My boss is a busy man; he doesn't close at the normal period and as his secretary you know what that means, am here till he leaves office (IDI, Female, Ado Ekiti)

Another respondent:

Actually I am not complaining, but not having somebody to assist me in taking care of the kids has been a major challenge; I am sure that it would have been easy assuming I have a house help or somebody to assist. My children are still very young, my husband doesn't work within the city, he comes home at fortnight, and sometimes at month end and am the only one taking care of the three of them... (IDI, Ado Ekiti).

Another respondent:

It is not easy... but combining the two are a necessity, you just have to do it... (IDI, Ado Ekiti).

The respondents (see Table 5) were asked to identify the major challenge facing them while combining work with motherhood; 34.3 percent attributed their main challenges to closing late from work; 18.8 percent claimed that the demands within the office was too tasking for them while 26.3 percent attributed it to the stress they face after the closing hour. 
The rest of the respondents (20.6percent) claimed that going home to tackle the domestic chores was their major challenge.

Table 5

Percentage Distribution of Respondents on the Challenges Faced and Implication on Mother and Child

\begin{tabular}{|l|l|l|}
\hline $\begin{array}{l}\text { Challenges Faced by } \\
\text { Mothers }\end{array}$ & Frequency & Percentage \\
\hline $\begin{array}{l}\text { Difficulty in combining } \\
\text { motherhood with job }\end{array}$ & 117 & 73.1 \\
\hline Financial problem & 43 & 26.9 \\
\hline Total & 160 & 100.0 \\
\hline $\begin{array}{l}\text { Perceived implications of } \\
\text { the challenges on child }\end{array}$ & Frequency & Percentage \\
\hline Malaria & 35 & 22.0 \\
\hline $\begin{array}{l}\text { Diarrhoea, loss of appetite } \\
\text { and weakness }\end{array}$ & 37 & 23.1 \\
\hline $\begin{array}{l}\text { Emotional and physical } \\
\text { discomfort }\end{array}$ & 88 & 54.9 \\
\hline Total & 160 & 100.0 \\
\hline $\begin{array}{l}\text { Perceived implication of } \\
\text { challenges on the mother }\end{array}$ & Frequency & Percentage \\
\hline $\begin{array}{l}\text { Loss of concentration at } \\
\text { work }\end{array}$ & 23 & 14.5 \\
\hline Stress and body weakness & 100 & 62.3 \\
\hline $\begin{array}{l}\text { Frequent disagreement } \\
\text { with spouse and } \\
\text { colleagues at work }\end{array}$ & 37 & 23.2 \\
\hline Total & 160 & 100.0 \\
\hline
\end{tabular}

Some of the responses of the respondents during the IDI are submitted below:

To me, working mothers having infants should be allowed to close early; in our workplace, you are allowed to close at $2 \mathrm{pm}$ for three months after resuming for maternity leave, but I feel this should be extended to 3 years. This will allow mothers to have time to take 


\section{Omotosho - Employment, Motherhood and Wellbeing}

care of their children till they are old enough to care for themselves, I think if this is addressed within the workplace, it will be a lot easier (IDI, Ado Ekiti).

Another respondent:

I am hopeful that I will get a car very soon; if this dream is realized, it will make my job easier as a mother, I would not have to go through the traffic stress, it will be easier to pack my children lunch while leaving in the morning and I think it will be a lot easier with a car... (IDI, Ado Ekiti).

Another respondent:

Everybody is always eager to leave at exactly $4 \mathrm{pm}$ (closing time), at this period, the whole place will be a mess due to traffic hold up, sometimes, I could spend up to 2 hours in the traffic... (IDI, Ado Ekiti).

Another respondent:

Getting home after work to cook and prepare for the next day is really an issue; it's like resuming for another work session after closing, even with house help, you will still need to supervise him/her to do the right thing.... It's not easy... (IDI, Ado Ekiti).

A number events are changing regarding the set up families across the globe (Ellison, Barker, Kulasuriya, 2009). For instance, parents in most societies across the globe now share the responsibilities of caring for their kids. This has made it easier for mothers to combine parenting and employment. However, data explaining how this is possible in Africa is however still lacking. From the data available in western world, a number of factors ranging from employment patterns, age of and number of the children within a family and ability to spend less hours have been argued to play key roles in determining the abilities of working mothers to easily combine parenting with their jobs

Further, majority of the respondents (87.5 percent) had crèche around their workplace and 72.5 percent of them patronized the place. The few respondents who were not patronizing the place attributed it to the fact that they do not like the place and that the crèche is expensive. While little information is available regarding the state of crèche facilities for nursing mothers within the workplace, what is obvious is that a quantum leap has been taken in this regard. A number of crèche facilities are emerging across workplaces, though this may not be adequate; apart from this, the 
traditional methods where relations namely grandmothers, and older siblings take care of their younger are still in place, though it has been criticized as having a negative effect on the child (Engle 1991; Leslie and Paolisso, 1989). Notwithstanding, these traditional methods still play key roles in providing care for the child.

This segment (see Table 5) describes the percentage distribution of respondents as regards the challenges they face and the perceived impact on them and their children. Findings revealed that about 73.1 percent claimed the challenges include how to combine work with mother hood while 26.9 percent attributed it to financial challenges in meeting their needs and that of their children. Their argument was that they engage in paid employment based on the need to get more money to take care of themselves and their children. Regarding the implications on them and their children, respondents claimed that their children experience diarrhoea and malaria (22.2 percent), loss of appetite and weakness (23.1 percent) while 54.9 percent claimed that their children experience some emotional discomfort like refusal to stay with child attendants. However, 23.0 percent claimed that their children did not show any negative symptoms as a result of their jobs. On the part of the mothers, 62.3 percent claimed that their major challenge as a result of combining work and motherhood includes stress and in ability to focus on their work. Further, 23.2 percent claimed they had frequent disagreements with their spouses over work related issues. Some of the IDI responses are captured below to corroborate this analysis:

My main issue with combining work and motherhood is the stress of crèche, some of the handlers of the centres may not be professional enough, they keep changing handlers which to me is not good for the children; by the time my child is getting used to a care giver, another one is brought, this has always made it difficult for my child to stay. I would need to pacify her before she could stay, even after leaving I would be summoned that my child needs my attention because she is always upset because of the environment. On the long run, I find it difficult to concentrate because sometimes I would be wondering if my baby has not started crying... (IDI, Ado Ekiti).

Another respondent gave her remarks:

My husband feels I should quit salaried job. He feels I need more time to stay with the kids. But if I would want to do that, where would the money come from? Sometimes this generates argument 
between me and my husband. Though I plan to leave as soon as we are able to gather enough money to start a business... (IDI, Ado Ekiti).

Several empirical works have explained the synergy between these variables (Blau and Grossberg, 1992; Ermisch and Francesconi, 2005; Berna, 2008). However, each scholar has taken different stands from neutral to extreme sides. This has made it a bit cumbersome to analyze. A number of factors have to be taken into consideration before a definite statement can be made regarding the impact mother's job on child. For instance, Mancini and Pasqua (2012) suggested that the number of time spent on children must be taken into consideration while Hsin, (2009) laid emphasis on the level of education of the mother as an important variable to consider.

The respondents (see Table 6) were asked on how they coped with motherhood and employment; respondents had different means by which they achieved this.

Table 6

Percentage Distribution of the Coping Strategies of the Respondents

\begin{tabular}{|l|l|l|}
\hline $\begin{array}{l}\text { How do you cope combining } \\
\text { motherhood with your job? }\end{array}$ & Frequency & Percentage \\
\hline Through child spacing & 12 & 7.5 \\
\hline $\begin{array}{l}\text { I ask for the help of nannies to } \\
\text { assist }\end{array}$ & 28 & 17.5 \\
\hline $\begin{array}{l}\text { My husband and myself both } \\
\text { carry the responsibility }\end{array}$ & 28 & 17.5 \\
\hline $\begin{array}{l}\text { I drop my child with crèche } \\
\text { before going to work }\end{array}$ & 40 & 25.0 \\
\hline $\begin{array}{l}\text { Mothers enjoy free hands in my } \\
\text { work place }\end{array}$ & 52 & 32.5 \\
\hline Total & 160 & 100.0 \\
\hline
\end{tabular}




\begin{tabular}{|l|l|l|}
\hline $\begin{array}{l}\text { What do you think can } \\
\text { alleviate the stress of } \\
\text { combining work and } \\
\text { motherhood }\end{array}$ & Frequency & Percentage \\
\hline Reduce working hour & 39 & 24.3 \\
\hline Special allowance & 78 & 48.8 \\
\hline Increase maternity leave periods & 43 & 26.9 \\
\hline Total & 160 & 100.0 \\
\hline
\end{tabular}

For instance 7.7 percent of the respondents claimed they spaced the birth of their children; 17.5 percent claimed they asked for the assistance of domestic help. Other respondents (17.5 percent) claimed that the assistance rendered by their spouses made it easy to survive; further, 25.0 percent argued that they relied on the facilities provided by day care centres while 48.8 percent argued that the working condition in their workplaces were not arduous. IDI conducted further shed light on the strategies adopted by the mothers to cope with challenges associated with motherhood and employment. Some of their comments are highlighted below:

It is easier to manage work and motherhood unlike what it used to be when I had my first baby. At that time, we didn't have a crèche around my office area but now we do. It was easier to visit the place and nurse my child when he was suckling and now that he has stopped, I still pay him visits in between office hours. At closing hour, I pick our second baby in the crèche while my husband brings our first son home from school... (IDI, Ado Ekiti).

Another respondent:

I think the work stress in this unit is very minimal; thus, you are allowed to check on your child at the day care centre as often as you want to. So my job demands doesn't have adverse effect on my role as a mother... (IDI, Ado Ekiti).

Another respondent:

We (myself and the rest of the family) all leave home at the same time and return at the same time in our car..., my office is closer to my house, I am usually the first person my husband drops off in the morning, so I just drop my baby in the crèche while my husband drops our other children in the school (they attend the same school). He follows the same routine in the afternoon, and to me 
this make it easier rather than me doing all the work. (IDI, Ado Ekiti).

Available evidences have always suggested that balancing work responsibilities and parenting is often a challenge (Parker and Wang, 2013), however, the outcome of such balancing exercise often reveals that parents are happy with the outcome of their efforts.

The respondents were also asked on how they think the stress of combining motherhood and employment be reduced; 24 . percent of the respondents suggested that office hours should be reduced; 48.8 percent of the respondents opined that there must be special allowances paid to working mothers to compensate for the stress while the remaining 26.9 percent felt that the present three months' maternity leave given to women after child birth be increased. Some of the IDI responses buttressing these arguments are captured below:

Mothers having toddlers should be allowed to close early; this will enable them have ample time to take care of the kids and also prepare for work. Apart from this, they should also give them more maternity leave periods (IDI, Ado Ekiti);

Another respondent gave her remarks:

We are told that in developed countries, there are special allowances for nursing mothers. They should introduce that in our country as well. Though this cannot really alleviate the stress, but it will go a long way in mitigating the effects as mothers will have enough money to secure the services of domestic help and further take care of the children.

\section{Test of hypotheses}

This section presents some findings regarding the statistical relationship among the variables tested for the study.

The first hypothesis states that there is a significant relationship between age and finding parenting and employment easy to cope with. As regards the chi-square test of association between age and finding parenting and employment easy to cope with, data revealed that there was a significant association between the variables (.000). By implication, age could play an important role in determining how easy it would be in combining motherhood and employment. Younger couples who have not 
had more than one child appears to find it easy to cope with the demands of motherhood and employment for a number of reasons. First they have just entered the business of procreation and thus it is fascinating for them rather than couples with more children. This may however not suggest that in most instances older women may find it more difficult in most cases than the young women. Older women with infants may find it easier to cope with work if they have older children that may assist them in taking care of their infants. This of course is not an alien culture in Africa where older children are expected to take care of their younger ones.

Data on significant relationship between marital status and finding parenting and employment easy revealed that statistically there was no significant association between both variables (.012). By implication, marital status may not have strong implications on respondents' ability to juggle between work and motherhood. IDI conducted further attests to this,

I live with my parents, so my mom takes care of my daughter when am away to work, sometimes the girl doesn't even miss me because she enjoys the company of my mom more than myself. Taking care of the kid is not an issue to me at all. My mother does it all. (IDI, Ado Ekiti).

Another respondent:

Combining my roles as a mother and a worker is not an easy task. I have about 3 of my husband's family members leaving with us- my mother-in-law and two others. To cater for these set of people including my two children plus my husband is really a big deal. Yet, I will still be expected to report early for work the following day. (IDI, Ado Ekiti).

A number of factors intervene in determining the ability of mothers to effectively combine parenting and work. For instance, it has been widely argued within literature that single mothers often find it difficult to combine work and parenting, yet other works have also opined that a number of factors like income of the single mother equally play important roles as well (Alberda, 2009). From this finding, the roles of significant others namely family members and friends may equally make the job easier for single mothers. The general assumption regarding married mothers is that they enjoy maximum support from family members but this may not be so in all situations. Traditionally, external influence and supports are minimal for 


\section{Omotosho - Employment, Motherhood and Wellbeing}

married mothers and they may have to depend on their husbands and very close relations for support which are usually time based.

Findings on the statistical relationship between respondents who give in their best to work often find motherhood and employment an easy task shows that a significant relationship exists between the variables (0.002). By implication those who give in their best in their work settings are likely to give in their best to motherhood. While this may be hard to explain, this phenomenon may suggest attitudinal issues as a strong determinant for success. This is because women in employment tend to perform in one aspect to the detriment of the other (Carr, Ash, Friedman, Scaramucci, Barnett, Szalacha, Palepu, Moskowitz, 1998). Studies have however affirmed a strong relationship between work preferences and attitudes (Hakim, 2001); however, studies have equally added that attitudes towards work are a combination of many factors ranging from educational attainment, their ethnic and social background, their employment record and age all play important roles in attitudes (Kangas and Rostgaard, 2007). Studies examining the linkage between success in work preferences and motherhood are however lacking.

\section{Conclusion and Recommendation}

This study explores how working mothers within public organisations juggles between parenting and employment. A number of issues became clear, first, combining work and motherhood is a difficult process for mothers. This challenge may continue considering the persistent demand of employers for effectiveness and productivity. Children and mothers may also continue to experience different kinds of challenges due to the demands in the workplace. Second further studies exploring issues surrounding working mothers within work settings in developing countries and especially in Africa is still needed. Data explaining the realities within these spaces are still limited to developed nations. The study recommends the need for both stakeholders (policy makers and employers of labour) to adopt means of ensuring working mothers are at their optimum capacities for parenting and career. 


\section{References}

Albelda, R. (2009). Why it's harder (and different) for single mothers: Gender, motherhood, labor markets and public work supports. Center for Social Policy and Department of Economics University of Massachusetts Boston January

Ammaniti, M., Ambruzzi M.; Lucarelli, L; Cimino, L; \& Linpio F.(2004). Malnutrition and dysfunctional mother-child feeding interaction: Clinical assessment and research implications. Journal of the American college of Nutrition Vol 23, No3, pp 259-271.

Barnett, R. C., Marshall, N. L., \& Sayer, A. (1992). Positive-spillover effects from job to home: A closer look. Women and Health, 19(2/3), 13-41.

Basu, A. (1992). Women economic roles and child health: An overview Presented at the International Conference on Population and Development [ICPD], Expert Group Meeting on Population and Women, Gaborone, Botswana, June 22-26. 17 p.

Berna, R. (2008). The Effect of Maternal Employment and Child Care on Children's Cognitive Development International Economic Review Vol. 49 , No.

4 ,

November https://economia.uniandes.edu.co/files/profesores/raquel_bern al/docs/IER_maternal_employment_print_version_4.pdf

Blau, F. D. \& Grossberg, A. J, (1992). "Maternal Labor Supply and Children's Cognitive Development," The Review of Economics and Statistics, MIT Press, vol. 74(3), pages 474-481, August.

Bolzendahl C., \& Meyers, D.J. (2004). Feminist attitudes and support for gender equality: Opinion change in women and men, 1974-1998. Social Forces 83(2):759-790.

Budig, M. \& England, P. (2001). The wage penalty for motherhood. American Sociological Review. 66, 204-225.

Carr P.L., Ash A.S., Friedman R.H., Scaramucci A., Barnett R.C, Szalacha L., Palepu A., \& Moskowitz M.A. (1998). Relation of family responsibilities and gender to the productivity and career satisfaction of medical faculty. Ann Intern Med., 129 (7): 532-538.

Charles N \& Harris C. (2007). Continuity and change in work-life balance choices. British Journal of Sociology 58 (2): 277-295. 
Chete, L.N., Adeoti, J.O., Adeyinka, F.M., \& Ogundele, O. (2014). Industrial development and growth in Nigeria: Lessons and challenges. Learning to Complete Working Paper (2114) No 8 http://www.brookings.edu/ /media/Research/Files/Papers/2014/11/learni ng-to-compete/L2C_WP8_Chete-et-al.pdf?la=en.

Correll, S., Bernard, S., \& Paik, I. (2007). Getting a Job: Is there a motherhood penalty? American Journal of Sociology. 112, 1297-1338.

Ellison, A., Barker, A., \& Kulasuriya, A.(2009). Work and care: a study of modern parents Equality and Human Rights Commission Research Report Series www.equalityhumanrights.com. Accessed on 21 January, 2016.

Engle, P. L. (1991). Maternal work and child-care strategies in peri-urban Guatemala: Nutritional effects. Child Development 62 (1991):954-965.

Ermisch, J. \& Nicoletti, C. (2005). "Intergenerational earnings mobility: Changes across cohorts in Britain" ISER Working Paper 19 https://www.iser.essex.ac.uk/files/iser working papers/2005-19.pdf

Falzon, J.(2007). The Role of the Mother in the Child's Development www.childabuse.suite101.com. Accessed on 13th Accessed on 13th may, 2015.

Gungor, G. \& Biernat, M. (2009). Gender bias or motherhood disadvantage? Judgments of blue collar mothers and fathers in the workplace. Sex Roles, 60, 232-246.

Hakim, C. (2001). Work-Lifestyle Choices in the Twenty-First Century: Preference Theory. Oxford: Oxford University Press.

Heilman, M. E. \& Okimoto, T. G. (2008). Motherhood: A potential source of bias in employment decisions. Journal of Applied Psychology, 93(1), 189-198.

Hein, C.; Cassirer, N. (2010). Workplace solutions for childcare Geneva, International Labour Office,

Hoffman, L.W. (1963). The effect of maternal employment on children The Employed Mother in America. Nye and Hoffman (eds) www.dowiley.com pp1469-7610.

Hsin, A. (2009). "Parent's Time with Children: Does Time Matter for Children's Cognitive Achievement?" Social Indicators Research, 93(1): $123-126$ 
International Labour Office (2010). World of work report 2010: from one crisis to the next? / International Labour Office. http://www.ilo.org/public/portugue/region/eurpro/lisbon/pdf/worl dwork_2010.pdf

Joekes, S. (1989). Women's work and social support for child care in the Third World in J. Leslie and M. Paolisso (Eds.), Women, Work, and Child Welfare in the Third World, Boulder, CO: Westview Press.

Kaiser Family Foundation. (2003). Women, work, and family health: A balancing act issue brief. April www.kff.org..

Kan, M.Y. (2007). Work orientation and wives' employment careers: An evaluation of Hakim's preference theory. Work and Occupations 34 (4): 430-462.

Kangas O., \& Rostgaard, T. (2007) Preferences or institutions? Wo.rk family life opportunities in seven European countries, Journal of European Social Policy 17 (3): 240-256.

Leslie, J., \& Paolisso, M. (1989). Women, work and child welfare in the Third World. AAAS Selected Symposia Series, Colorado: (Westview Press).

Leslie, J. (1989). Woman's Work and Child Nutrition in the Third World in J. Leslie and M. Paolisso (Eds.), Women, Work, and Child Welfare in the Third World, Boulder, CO: (Westview Press).

Mancini, A.L., \& Pasqua, S. (2012). "Asymmetries and Interdependencies in Time Use Between Italian Parents". Applied Economics, 44(32), 41534171

Omoruyi O. (1994). et al (Eds) Democratization in Africa- Nigeria perspectives. Vol.2 Benin city- Centre for Democratic Studies. P. 101.

Orr, J. (1997). Working mothers: The double shift Socialist Review. (Issue 206,).

Parker, K., \& Wang, W. (2013). Roles of Moms and Dads Converge as They Balance Work and Family Modern Parenthood March 14. Pew Research Center http://www.pewsocialtrends.org/2013/03/14/modern-parenthoodroles-of-moms-and-dads-converge-as-they-balance-work-and-family/ accessed on 15th February, 2016.

Ridgeway, C. \& Correll, S. (2004). Motherhood as a status characteristic. The Journal of Social issues, (60), 683-700. 
1287 Omotosho - Employment, Motherhood and Wellbeing

Sun news online. (2013). Gender policies: The odds against women in Nigeria http://sunnewsonline.com/new/gender-policies-the-odds-againstwomen-in-nigeria/ accessed on 13th May, 2015.

Williams, C.L. (1992). The glass escalator: hidden advantages for men in the 'female' professions. Social Problems. (Vol 39, No 3, August). Pp 253267.

Babatunde JoshuaOmotosho, senior lecturer

Contact address:

Federal University Oye-Ekiti. Department of Sociology, P.M.B 373, Oye-Ekiti, Ekiti State, NIGERIA.

E-mail address: babatundeomotosho@gmail.com 